\title{
HUBUNGAN USIA IBU BERSALIN, PARITAS DAN BERAT BAYI LAHIR DENGAN KEJADIAN PARTUS TAK MAJU
}

\author{
Paskalia Tri Kurniati*
}

Program Studi Kebidanan, STIKes Kapuas Raya

Email: liakurniati14@gmail.com

Masuk: 17-11-2020, revisi: 20-03-2021, diterima untuk diterbitkan: 24-03-2021

\begin{abstract}
ABSTRAK
Sekitar 9\% kematian maternal akibat komplikasi selama kehamilan, persalinan dan setelah persalinan. Penyebab kematian ibu perdarahan 30,1\%, hipertensi 26,9\%, infeksi 5,6\%, abortus 1,6\%, partus tak maju 1,8\% dan lain-lain 34,5\%. Data yang diperoleh di RSUD Ade Mohammad Djoen selama 3 tahun terakhir terjadi peningkatan kasus partus tak maju. Tahun 2017 ada 37 kasus, tahun 2018 ada 39 kasus, dan tahun 2019 menjadi 48 kasus. Tujuan penelitian ini mengetahui Hubungan Usia Ibu Bersalin, Paritas dan Berat Bayi Lahir dengan Kejadian Partus Tak Maju. Metode Penelitian adalah analitik kuantitatif dengan desain cross sectional, menggunakan pendekatan retropektif. Hasil penelitian ini ada hubungan usia ibu bersalin dengan kejadian partus tak maju dengan ( $\mathrm{p}$ value $=$ 0,008 ( $\mathrm{p}<0,05$ ) dan nilai OR 2,250 yang berarti usia ibu bersalin yang <20 Tahun atau >35 tahun mempunyai resiko terjadinya partus tak maju 2,250 kali lebih besar. Ada hubungan paritas dengan kejadian partus tak maju dengan $(\mathrm{p}$ value $=0,026(\mathrm{p}<0,05)$ dengan nilai OR 1,977 yang artinya paritas dengan jumlah persalinan 1 atau $>3$ mempunyai resiko terjadinya partus tak maju 1,977 kali. Ada hubungan antara berat bayi lahir dengan kejadian partus tak maju dengan ( $\mathrm{p}$ value $=0,040(\mathrm{p}<0,05)$ dengan nilai OR 1,953 yang artinya berat bayi lahir yang beresiko >4000 gram mempunyai resiko terjadinya partus tak maju 1,953 kali lebih besar. Saran dalam penelitian ini perlu meningkatkan inovasi pelayanan dalam menangani kegawatdaruratan partus tak maju salah satunya melalui langkah penapisan sejak awal dengan pemeriksaan kehamilan sehingga kasus partus tak maju dapat dicegah.
\end{abstract}

Kata Kunci $\quad$ : Berat Bayi Lahir; Partus Tak Maju; Usia Ibu Bersalin; Paritas

\begin{abstract}
About $9 \%$ of maternal deaths are due to complications during pregnancy, childbirth and after delivery. The cause of maternal death was bleeding 30.1\%, hypertension $26.9 \%$, infection $5.6 \%$, abortion $1.6 \%$, prolonged labor $1.8 \%$ and others 34.5\%. Data obtained at the Ade Mohammad Djoen Regional Hospital for the last 3 years has seen an increase in cases of prolonged labor. In 2017 there were 37 cases, in 2018 there were 39 cases, and in 2019 there were 48 cases. The purpose of this study was to determine the relationship between maternal age, parity and birth weight with the incidence of non-progressive labor. The research method is quantitative analytic with cross sectional design, using a retropective approach. The results of this study showed a relationship between maternal age and the incidence of prolonged labor with ( $p$ value $=0.008(p<0.05)$ and an OR value of 2,250, which means that the age of mothers who gave birth who was $<20$ years or $>35$ years had a risk of developing non-progressive labor 2,250. There is a relationship between parity and the incidence of underdeveloped labor ( $p$ value $=0.026$ ( $p$ $<0.05)$ with an OR value of 1.977, which means parity with the number of deliveries 1 or $>3$ has a risk of developing non-progressive labor by 1.977 times. Between the birth weight and the incidence of non-progressive labor with ( $p$ value $=0.040$ ( $p<0.05)$ with an OR value of 1.953, which means that the birth weight at risk $>4000$ grams has a 1.953 times greater risk of developing prolonged labor. This needs to increase service innovation in dealing with emergencies of underdeveloped labor, one of which is through early screening steps with antenatal care so that cases of prolonged labor can be prevented.
\end{abstract}

Keywords $\quad$ : birth weight; Prolonged labor; maternal age; parity 


\section{PENDAHULUAN}

Saat ini keberhasilan dalam bidang kesehatan ibu dapat diperhatikan dari indikator Angka Kematia Ibu (AKI). AKI merupakan jumlah kematian ibu selama masa kehamilan, persalinan, dan nifas yang disebabkan oleh kehamilan, persalinan, dan nifas atau pengelolaannya setiap 100.000 kelahiran hidup (Kemenkes RI, 2015). Angka Kematian Ibu (AKI) di dunia berdasarkan laporan WHO pada tahun 2003, didapatkan bahwa dalam setiap menit seorang wanita meninggal karena komplikasi yang terjadi. Komplikasi ini terkait dengan proses kehamilan dan persalinannya. Dilaporkan juga sebanyak $99 \%$ kematian yang terjadi pada ibu di dunia terjadi di negara-negara berkembang (Fatoni, 2011)

Berdasarkan laporan WHO pada tahun 2017, sekitar 810 wanita meninggal dunia akibat komplikasi yang tidak dapat dicegah pada masa kehamilan dan persalinan. Sejak tahun 2000 hingga 2017, rasio kematian ibu turun sekitar 38\% di seluruh dunia. 94\% dari semua kematian ibu terjadi di negara berpenghasilan rendah dan menengah ke bawah (WHO, 2019). AKI di negara-negara seperti Asia Tenggara yaitu Indonesia sebanyak 214/100.000 kelahiran hidup, di negara Filipina tercatat sebanyak 170/100.000 kelahiran hidup, negara Vietnam tercatat 160/100.000 kelahiran hidup, Thailand sebanyak 44/100.000 kelahiran hidup, di negara Brunei tercatat 60/100.000 kelahiran hidup, dan di negara Malaysia tercatat sebanyak 39/100.000 kelahiran hidup (WHO, 2014).

Mengutip data dari Sensus Penduduk (SUPAS) yang dilakukan pada tahun 2015, dimana data ini melaporkan bahwa AKI di Negara Indonesia sebesar 305/100.000 kelahiran hidup (SUPAS, 2015). Penyebab kejadian AKI ini adalah kejadian perdarahan sebanyak 30,1\%, infeksi yang dialami oleh ibu sebanyak 5,6\%, kejadian abortus sebanyak 1,6\%, kejadian partus tak maju sebanyak 1,8\% dan lain-lain sebanyak 34,5\% (Kemenkes RI, 2014).

Sebelumnya telah diketahui bersama, bahwa tiga besar penyebab kematian yang dialami oleh ibu dalam bidang obgyn adalah perdarahan $45 \%$, infeksi $15 \%$, dan hipertensi dalam kehamilan (preeklampsi) 13\%. Selain itu, masalah lain yang juga menyebabkan angka kematian ibu meningkat adalah partus tak maju (dimana proses partus lebih dari 18 jam) yang merupakan salah satu dari beberapa penyebab kematian pada ibu dan juga mengakibatkan kematian pada bayi baru lahir. Partus tak maju rata-rata di dunia dapat menyebabkan kematian ibu sebesar $8 \%$ dan di negara Indonesia sendiri sebesar 9\% kematian pada ibu disebabkan oleh kejadian partus tak maju. Partus tak maju merupakan salah satu penyebab kematian ibu karena partus tak maju akan menyebabkan infeksi, kehabisan tenaga saat ibu mengedan, dehidrasi pada ibu, dan dapat juga menyebabkan perdarahan post partum yang sangat membahayakan keselamatan ibu (Fatoni, 2011).

Kejadian partus tak maju merupakan proses persalinan yang mana berlangsung lebih dari 24 jam pada ibu dengan kehamilan primi, dan lebih dari 18 jam pada ibu dengan kehamilan multi. Partus tak maju merupakan fase dari suatu partus yang macet dan berlangsung terlalu lama sehingga menimbulkan gejala-gejala seperti dehidrasi, infeksi, kelelahan, serta, asfiksia dan kematian dalam kandungan (Purwaningsih, 2010). Proses persalinan adalah suatu proses pengeluaran hasil konsepsi (janin atau uri) yang telah cukup bulan atau dapat hidup di luar kandungan melalui jalan lahir atau jalan lain dengan bantuan ataupun tanpa bantuan (menggunakan kekuatan dari ibu sendiri). Sedangkan persalinan kala II yaitu mulai pembukaan lengkap $(10 \mathrm{~cm})$ sampai dengan lahirnya bayi, yang mana proses tersebut berlangsung rata-rata 90 menit, 50 menit pada ibu dengan primigravida, dan rata-rata 30 menit, sedangkan pada multigravida 20 menit (Manuaba, 2010). 
Proses persalinan pada kala II sangat dipengaruhi oleh tiga faktor yang bekerja yang sangat berperan yang mana tiga hal tersebut adalah kekuatan untuk mendorong janin agar keluar atau yang dikenal dengan (power) yang meliputi his (kekuatan uterus), kontraksi pada otot dinding perut, kontraksi diafragma dan ligamentum. Faktor kedua adalah faktor janin (passanger) yang meliputi besarnya janin, berat bayi baru lahir dan lainnya. Faktor ketiga yang berpengaruh terhadap proses persalinan adalah jalan lahir (passage) yang meliputi tulang-tulang panggul, otot-otot, jaringan, dan ligament-ligament. Dalam hal ini, apabila dari ketiga faktor ini dalam kondisi yang baik, sehat dan seimbang, maka proses persalinan yang dilalui oleh seorang ibu akan berlangsung secara normal/spontan. Namun apabila salah satu dari ketiga faktor tersebut mengalami kelainan, misalnya keadaan yang menyebabkan kekuatan dari his yang tidak adekuat, kelainan pada bayi atau kelainan jalan lahir maka proses persalinan pada kala II akan bisa terganggu prosesnya (Eka, 2014).

Usia pada saat ibu melahirkan juga saat berpengaruh dalam proses persalinan. Usia ibu kurang dari 20 tahun dan lebih dari 35 tahun memiliki resiko tinggi yang kemungkinan akan memberikan ancaman kesehatan dan jiwa ibu maupun janin yang dikandungnya selama kehamilan. Anang (2011) dalam penelitiannya yang berjudul Hubungan usia ibu, paritas, dan berat lahir terhadap persalinan macet di RS Adji Darmo Lebak menemukan hasil bahwa adanya hubungan antara variabel usia ibu dengan kejadian partus macet atau yang dikenal juga dengan istilah partus tak maju. Hal ini disebabkan oleh semakin bertambah usia seseorang dalam proses persalinan akan sangat berpengaruh terhadap kemampuan dan kekuatan ibu saat melangsungkan proses kelahiran.

Faktor penyebab lainnya juga yang berpengaruh pada kejadian partus tak maju adalah paritas. Paritas menunjukkan jumlah anak yang dilahirkan oleh seorang wanita. Paritas merupakan faktor penting dalam menentukan nasib ibu dan janin baik selama kehamilan maupun selama persalinan. Pada ibu dengan primipara (wanita yang melahirkan bayi hidup pertama kali) karena pengalaman melahirkan belum pernah maka kemungkinan terjadinya kelainan dan komplikasi cukup besar (Hermia, 2011). Mempunyai anak lebih dari empat orang juga, akan menmabha resiko terhadap ibu dan bayinya, lebih-lebih jarak kehamilan kurang dari dua tahun, maka ibu akan lemah akibat seringnya hamil, melahirkan, menyusui, dan merawat anaknya sehingga mengakibatkan berbagai masalah (Manuaba, 2010).

Berdasarkan hasil data sensus penduduk yang dilakukan pada tahun 2010, AKI di Provinsi Kalimantan Barat tercatat ssebesar 240 per 100.000 kelahiran hidup, yang mana untuk angka yang tercatat secara nasional sebesar 259 per 100.000 kelahiran hidup (Kebijakan Pembangunan Kesehatan dan 5 Isu Strategis, 2019). Hal ini menunjukkan bahwa angka kematian yang terjadi pada ibu di Kalimantan Barat telah terjadi penurunan yang sangat signifikan, dimana dalam dua dasawarsa, pada tahun 2012 angka kematian ibu di Kalimantan Barat berada dibawah angka nasional. Jika dibandingkan dengan data yang terlapor dalam SDKI maupun yang terlaporkan dalam data hasil sensus penduduk. Sedangkan, jika dilihat berdasarkan kasus kematian maternal yang terjadi pada tahun 2018 di provinsi Kalimantan Barat, tercatat sebanyak 98 kasus kematian ibu. Sehingga jika dihitung angka kematian ibu maternal dengan jumlah dari kelahiran hidup terlaporkan sebanyak 86.572, dimana dengan jumlah kematian ibu maternal di provinsi Kalimantan Barat sebesar 113 per 100.000 kelahiran hidup. Pada tahun 2018, AKI di Provinsi Kalimantan Barat dilaporkan ada 86 kasus kematian pada ibu, jika dihitung angka kematian ibu maternal dengan jumlah kelahiran hidup dilaporkan sebanyak 90.913, maka kematian maternal ibu 95 per 100.000. Di Kabupaten Sintang jumlah kematian ibu bersalin pada tahun 2018 
sebanyak 133 kasus, dan merupakan urutan terbesar ketiga di wilayah Propinsi Kalimantan Barat (Profil Kesehatan Provinsi Kalimantan Barat, 2018).

Berdasarkan hasil studi pendahuluan yang peneliti lakukan di RSUD Ade. M. Djoen melalui data rekam medik, pada tahun 2017 dari 1530 persalinan terdapat 37 kasus partus tak maju. Pada tahun 2018 partus tak maju mengalami peningkatan yaitu dari 1530 persalinan terdapat 39 kasus persalinan tak maju. Pada tahun 2019 mengalami peningkatan kembali kejadian partus tak maju menjadi 48 kasus dari total persalinan 1338. Dari data rekam medis, partus tak maju ini bisa di sebabkan oleh faktor ibu seperti umur ibu yang <20 tahun, 20-35 tahun dan >35 tahun serta jumlah persalinan ibu, faktor janin yaitu janin yang besar dan kelainan letak janin (Data Rekam Medis RSUD Ade Muhhamad Djoen, 2020).

Berdasarkan latar belakang yang telah peneliti uraikan di atas, maka peneliti merasa sangat perlu melakukan penelitian untuk mengetahui apakah ada "Hubungan Usia Ibu Bersalin, Paritas, dan Berat Bayi Lahir dengan Kejadian Partus Tak Maju di Rumah Sakit Umum Daerah Ade. M. Djoen Sintang Tahun 2020”.

Tujuan dari penelitian ini untuk mengetahui hubungan antara usia ibu bersalin, paritas dan berat bayi lahir dengan kejadian partus tak maju di RSUD Ade Muhammad Djoen Sintang. Penelitian ini juga bermanfaat sebagai bahan pengembangan dalam upaya peningkatan penanganan partus tak maju pada ibu bersalin.

\section{METODE}

Metode Penelitian adalah analitik kuantitatif dengan desain cross sectional, menggunakan pendekatan retropektif. Desain cross sectional adalah desain penelitian di mana peneliti mengamati atau mengambil data penelitian pada suatu waktu yang sama (Notoatmodjo, 2010). Populasi dalam penelitian ini adalah seluruh ibu bersalin di RSUD Ade. Muhammad Djoen pada tahun 2019 sebanyak 1504 ibu. Teknik sampel yang digunakan dalam penelitian ini adalah probability sampling dengan simple random sampling. Penentuan besar sampel yang digunakan dalam penelitian ini dengan menggunakan rumus Slovin dengan hasil perhitungan matematis didapatkan hasil 346 sampel. Pengumpulan data menggunakan data sekunder dari data rekam medik, intrumen penelitian yaitu lembar check-list. Pendekatan penelitian dengan menganalisa dokumentasi rekam medis kasus partus tak maju apakah ada hubungan antara usia ibu bersalin, paritas, dan berat bayi lahir terhadap kejadian partus tak maju pada ibu bersalin di Rumah Sakit Ade Muhammad Djoen Sintang Tahun 2020. Penelitian ini dilaksanakan pada bulan Mei tahun 2020.

\section{HASIL}

Setelah dilakukan pengumpulan data, dilakukan analisis data dengan menggunakan distribusi frekuensi yang selanjutnya disajikan dalam bentuk tabel dan narasi sebagai berikut:

\section{Analisa Univariat}

Analisis univariat digunakan untuk menggambarkan karakteristik semua variabel penelitian dengan cara menyusun tabel distribusi frekuensi untuk masing-masing variabel bebas dan terikat. 
1) Distribusi Frekuensi Usia Ibu Bersalin

Tabel 1. Distribusi Frekuensi Usia Ibu Bersalin di RSUD Ade. M. Djoen Sintang tahun 2020

\begin{tabular}{cccc}
\hline No & Usia Ibu Bersalin & F & $\mathbf{( \% )}$ \\
\hline $\mathbf{1}$ & Berisiko $(<20$ dan $>35$ tahun) & 95 & $27,5 \%$ \\
$\mathbf{2}$ & Tidak Berisiko (20-35 tahun) & 251 & $72,5 \%$ \\
\hline & Total & 346 & $100,0 \%$ \\
\cline { 2 - 2 } 2020 &
\end{tabular}

Berdasarkan tabel 4.1 didapatkan dari 346 sampel ibu bersalin sebagian kecil ibu bersalin dengan usia berisiko ( $<20$ tahun dan $>35$ tahun) sebanyak 95 orang $(27,5 \%)$ dan sebagian besar ibu bersalin usia tidak berisiko (20-35 tahun) sebanyak 251 orang $(72,5 \%)$.

\section{2) Distribsi Frekuensi Paritas}

Tabel 2. Distribusi Frekuensi Paritas di RSUD Ade.M. Djoen Sintang Tahun 2020

\begin{tabular}{|c|c|c|c|}
\hline & Paritas & $\mathbf{F}$ & $(\%)$ \\
\hline 1 & 1 atau $>3$ & 102 & $29,5 \%$ \\
\hline 2 & $2-3$ & 244 & $70,5 \%$ \\
\hline & Total & 346 & $100,0 \%$ \\
\hline
\end{tabular}

Berdasarkan tabel 4.2 didapatkan hasil sebagian kecil ibu bersalin dengan paritas 1 atau $>3$ sebanyak 102 orang $(29,5 \%)$ dan sebagian besar ibu bersalin dengan paritas 2-3 sebanyak 244 orang $(70,5 \%)$.

\section{3) Distribsi Frekuensi Berat Bayi Lahir}

Tabel 3. Distribusi Frekuensi Berat Bayi Lahir di RSUD Ade.M. Djoen Sintang Tahun 2020

\begin{tabular}{clcc}
\hline No & Berat Bayi Lahir & F & $\mathbf{( \% )}$ \\
\hline $\mathbf{1}$ & Berisiko $(>4000$ gr) & 80 & $23,1 \%$ \\
$\mathbf{2}$ & Tidak Berisiko $(\leq 4000$ gr $)$ & 266 & $76,9 \%$ \\
\hline & Total & 346 & $100 \%$ \\
\hline
\end{tabular}

Sumber : Data Sekunder dari Rekam Medik RSUD Ade. M. Djoen Sintang tahun 2020

Berdasarkan tabel 4.3 didapatkan hasil sebagian kecil ibu bersalin dengan berat bayi lahir berisiko ( $\geq 4000$ gram) sebanyak 80 orang $(23,1 \%)$ dan sebagian besar ibu bersalin dengan berat bayi lahir tidak berisiko ( $\leq 4000$ gram) sebanyak 266 orang $(76,9 \%)$.

\section{4) Distribusi Frekuensi Partus Tak Maju}

Tabel 4. Distribusi Frekuensi Partus Tak Maju di RSUD Ade Muhammad Djoen Sintang Tahun 2020

\begin{tabular}{cccc}
\hline No & Persalinan & F & $\mathbf{( \% )}$ \\
\hline $\mathbf{1}$ & Ya & 62 & $17,9 \%$ \\
$\mathbf{2}$ & Tidak & 284 & $82,1 \%$ \\
\hline & Total & 346 & $100 \%$ \\
\hline
\end{tabular}

Sumber : Data Sekunder dari Rekam Medik di RSUD Ade.M. Djoen Sintang Tahun 2020 
Berdasarkan tabel 4.4 didapatkan hasil sangat sedikit ibu bersalin dengan kejadian partus tak maju sebanyak 62 orang $(17,9 \%)$ dan hampir seluruh ibu bersalin dengan bukan partus tak maju sebanyak 284 orang $(82,1 \%)$.

\section{Analisa Bivariat}

Analisa bivariat yang digunakan dalam penelitian ini digunakan untuk mengetahui hubungan antara variabel, yaitu antara variabel bebas dan juga variabel terikat, seperti yang diuraikan dalam tabel dibawah ini;

Tabel 5. Hubungan Usia Ibu Bersalin, Paritas dan Berat Bayi Lahir dengan Kejadian Partus Tak Maju di RSUD Ade Muhammad Djoen Sintang Tahun 2020

\begin{tabular}{|c|c|c|c|c|c|c|c|c|}
\hline \multirow[t]{3}{*}{ Usia Ibu Bersalin } & \multicolumn{4}{|c|}{ Partus Tak Maju } & \multirow{2}{*}{\multicolumn{2}{|c|}{ Total }} & \multirow[t]{3}{*}{$P$ value } & \multirow{3}{*}{$\begin{array}{c}\text { OR } \\
\text { (Odds } \\
\text { Ratio) }\end{array}$} \\
\hline & \multicolumn{2}{|c|}{ Ya } & \multicolumn{2}{|c|}{ Tidak } & & & & \\
\hline & $\mathrm{n}$ & $\%$ & $\mathrm{~N}$ & $\%$ & $\mathrm{n}$ & $\%$ & & \\
\hline \multicolumn{9}{|l|}{ Usia Ibu Bersalin } \\
\hline Berisiko $(<20$ dan $>35)$ & 26 & 27,4 & 69 & 72,6 & 95 & 100 & 0,008 & \multirow{3}{*}{2,250} \\
\hline Tidak Berisiko(20-35) & 36 & 14,3 & 215 & 85,7 & 251 & 100 & & \\
\hline Jumlah & 62 & 17,9 & 284 & 82,1 & 346 & 100 & & \\
\hline \multicolumn{9}{|l|}{ Paritas } \\
\hline 1 atau $>3$ & 26 & 25,5 & 76 & 74,5 & 102 & 100 & 0,02 & 1,977 \\
\hline $2-3$ & 36 & 14,8 & 208 & 85,2 & 208 & 100 & & \\
\hline Jumlah & 62 & 17,9 & 284 & 82,1 & 346 & 100 & & \\
\hline \multicolumn{9}{|l|}{ Berat Bayi Lahir } \\
\hline Berisiko $(\geq \mathbf{4 0 0 0})$ & 21 & 26,3 & 59 & 73,8 & 73 & 100 & & \\
\hline Tidak Berisiko $(\leq 4000)$ & 41 & 15,4 & 225 & 84,6 & 273 & 100 & 0,040 & 1,953 \\
\hline Jumlah & 62 & 17,9 & 284 & 82,1 & 346 & 100 & & \\
\hline
\end{tabular}

Berdasarkan tabel 4.5 didapatkan hasil usia ibu bersalin yang berisiko yang mengalami partus tak maju sebanyak 26 orang $(27,4 \%)$ dan usia ibu bersalin yang tidak berisiko yang mengalami partus tak maju sebanyak 36 orang $(14,3 \%)$. Hasil uji statistik didapatkan nilai p value $=0,008$ (p.value $\leq \alpha=0,05$ ), dengan nilai $\mathrm{OR}=2,250$ yang artinya usia ibu bersalin yang berisiko yaitu $<20$ tahun dan >35 tahun mempunyai resiko terjadinya partus tak maju 2,250 kali lebih besar dari usia ibu bersalin yang tidak berisiko.

Hasil analisa variabel paritas dengan jumlah riwayat persalinan sebanyak 1 kali atau $>3$ kali yang berisiko mengalami partus tak maju sebanyak 26 orang $(25,5 \%)$ dan paritas dengan jumlah persalinan sebanyak 2-3 kali yang mengalami partus tak maju sebanyak $36(14,8 \%)$. Hasil uji statistik didapatkan nilai p value $=0,026$ (p.value $<\alpha=0,05$ ), maka Ho ditolak dan Ha diterima yang artinya ada hubungan antara paritas dengan kejadian partus tak maju. Nilai OR $=1,977$ yang artinya paritas dengan jumlah persalinan 1 atau $>3$ mempunyai resiko terjadinya partus tak maju 1,977 kali lebih besar dari paritas dengan jumlah persalinan 2-3 kali.

Hasil analisa bivariat antara variabel berat bayi lahir yang berisiko yang mengalami partus tak maju sebanyak 21 orang $(26,3 \%)$ dan berat bayi lahir yang tidak berisiko sebanyak 41 orang $(15,4 \%)$. Hasil uji statistik didapatkan nilai $\mathrm{p}$ value $=0,040$ (p.value $<\alpha=0,05$ ), maka Ho ditolak dan Ha diterima yang artinya ada hubungan antara berat bayi lahir dengan kejadian partus tak maju. Nilai $\mathrm{OR}=1,953$ yang artinya berat bayi lahir yang beresiko $>4000$ gram mempunyai resiko terjadinya partus tak maju 1,953 kali lebih besar dari berat bayi lahir yang tidak berisiko. 


\section{PEMBAHASAN}

\section{Hubungan Usia Ibu Bersalin dengan Partus Tak Maju}

Hasil analisis bivariat dari 346 orang ibu bersalin yang berisiko terdapat 26 orang $(27,4 \%)$ dan usia ibu bersalin yang tidak berisiko yang mengalami partus tak maju sebanyak 36 orang $(14,3 \%$ ). Hasil uji statistik didapatkan nilai $p$ value $=0,008$ (p.value $\leq \alpha=0,05$ ), dengan nilai OR $=2,250$ yang artinya usia ibu bersalin yang berisiko yaitu $<20$ tahun dan $>35$ tahun mempunyai resiko terjadinya partus tak maju 2,250 kali lebih besar dari usia ibu bersalin yang tidak berisiko.

Hasil penelitian yang dilakukan sebelumnya menyatakan bahwa sebagian responden yang mengalami persalinan tak maju sebagian besar merupakan usia yang berisiko, yaitu 26 responden $(68,4 \%)$ dan sangat sedikit responden usia tidak berisiko yang mengalami persalinan tak maju yaitu 12 responden $(15,8 \%)$. Pengujian hipotesis memberikan hasil $\mathrm{p}$ value $=0.049(\mathrm{p}$ $<0,05$ ) dan nilai OR (Odds Ratio) = 3,923 yang berarti ada hubungan antara usia ibu bersalin dengan kejadian persalinan tak maju (Fatoni, 2011). Usia ibu yang bersalin kurang dari 20 tahun atau juga lebih dari 35 tahun sangat memiliki resiko terhadap masalah persalinan lama atau persalinan tak maju. Dimana masalah ini lebih besar dibandingkan dengan usia ibu yang melahirkan di rentang usia 20-35 tahun. Umur ibu yang melahirkan di usia yang terlalu muda atau terlalu tua dianggap sangat penting dan sangat menentukan prognosis persalinan, karena sangat dapat membawa risiko khususnya persalinan tak maju (Varney, 2013).

Tidak semua ibu dengan usia kurang dari 20 tahun atau lebih dari 35 tahun dipastikan mengalami partus tak maju, akan tetapi pada sebagian wanita dengan usia yang masih muda organ reproduksinya masih belum begitu sempurna dan fungsi hormon-hormon yang berhubungan dengan persalinan juga belum sempurna pula. Ditambah dengan keadaan psikologis, emosional dan pengalaman yang belum pernah dialami sebelumnya dan mempengaruhi kontraksi uterus menjadi tidak aktif, yang nantinya akan mempengaruhi lamanya persalinan. Sedangkan pada ibu dengan usia lebih dari 35 tahun diketahui kerja organ-organ reproduksinya sudah mulai lemah, dan tenaga ibu pun sudah mulai berkurang, hal ini akan membuat ibu kesulitan untuk mengejan yang pada akhirnya apabila ibu terus menerus kehilangan tenaga karena mengejan akan terjadi partus tak maju.

\section{Hubungan Paritas dengan Kejadian Partus Tak Maju}

Hasil analisa bivariat dari 346 responden dengan variabel hubungan paritas dengan jumlah riwayat persalinan sebanyak 1 kali atau > 3 kali yang berisiko mengalami partus tak maju sebanyak 26 orang $(25,5 \%)$ dan paritas dengan jumlah persalinan sebanyak 2-3 kali yang mengalami partus tak maju sebanyak $36(14,8 \%)$. Hasil uji statistik didapatkan nilai $\mathrm{p}$ value $=$ 0,026 (p.value $<\alpha=0,05$ ), maka Ho ditolak dan Ha diterima yang artinya ada hubungan antara paritas dengan kejadian partus tak maju. Nilai OR $=1,977$ yang artinya paritas dengan jumlah persalinan 1 atau >3 mempunyai resiko terjadinya partus tak maju 1,977 kali lebih besar dari paritas degan jumlah persalinan 2-3 kali.

Hasil penelitian yang dilakukan sebelumnya menyatakan bahwa ada hubungan antara paritas dengan partus lama $(\mathrm{p}=0,000)$ dan $\mathrm{OR}=7,013$. Pada penelitian ini partus tak maju lebih banyak dialami oleh ibu dengan paritas 2-3 sebesar 51 orang $(63,75)$, sedangkan ibu dengan paritas 1 atau $>3$ sebesar 29 orang $(36,25 \%)$. Ibu hamil dengan primipara (wanita yang melahirkan bayi hidup pertama kali) karena pengalaman melahirkan belum pernah maka kemungkinan terjadinya kelainan dan komplikasi cukup besar (Hermia, 2011). Sedangkan yang memiliki paritas 4 kali atau lebih, kemungkinan mengalami gangguan kesehatan, kekendoran pada dinding rahim sehingga beresiko mengalami kelainan letak pada janin, persalinan letak lintang, robekan rahim, 
persalinan tak maju dan perdarahan pasca persalinan (Manuaba, 2010). Selain itu ibu hamil yang mempunyai anak lebih dari empat orang juga akan menambah resiko terhadap ibu dan bayinya, lebih-lebih jarak atara kehamilan kurang dari dua tahun, maka ibu akan lemah akibat seringnya hamil, melahirkan, menyusui, dan merawat anak-anaknya sehingga mengakibatkan berbagai masalah (Lusiana, 2014).

\section{Hubungan Berat Bayi Lahir dengan Kejadian Partus Tak Maju}

Hasil analisis bivariat antara variabel berat bayi lahir yang berisiko yang mengalami partus tak maju sebanyak 21 orang $(26,3 \%)$ dan berat bayi lahir yang tidak berisiko sebanyak 41 orang $(15,4 \%)$. Hasil uji statistik didapatkan nilai $\mathrm{p}$ value $=0,040$ ( $\mathrm{p}$.value $<\alpha=0,05$ ), maka Ho ditolak dan Ha diterima yang artinya ada hubungan antara berat bayi lahir dengan kejadian partus tak maju. Nilai $\mathrm{OR}=1,953$ yang artinya berat bayi lahir yang beresiko $>4000$ gram mempunyai resiko terjadinya partus tak maju 1,953 kali lebih besar dari berat bayi lahir yang tidak berisiko.

Hasil penelitian yang telah peneliti lakukan ini sama juga dengan hasil penelitian yang dilakukan sebelumnya yang menyatakan terdapat hubungan antara berat bayi lahir dengan kejadian partus lama di RS AL Jala Ammari Makasar Januari-April 2019 dengan p value = 0,000 ( $\mathrm{p}<0,05)$. Berat badan janin dapat mempengaruhi proses persalinan. Berat badan bayi lahir merupakan salah satu tolak ukur untuk mengetahui berat badan neonatus pada saat kelahiran yang ditimbang dalam waktu satu jam setelah lahir. Berat bayi lahir dapat menyebabkan distosia pada proses persalinan, yang ditandai dengan tidak adanya kemajuan persalinan, ini menyebabkan persalinana menjadi lama (Ruqaiyah, 2019).

Berat bayi lahir yang beratnya lebih dari 4000 gram atau bayi yang besar merupakan faktor partus tak maju yang sangat berkaitan dengan terjadinya malposisi dan malpresentasi, janin yang dalam keadaan malpresentasi dan malposisi kemungkinan besar akan menyebabkan partus tak maju. Kesulitan yang ditimbulkan dalam persalinan ialah karena besarnya kepala atau besarnya bahu, karena regangan dinding rahim, oleh anak yang sangat besar dapat timbul inertia dan kemungkinan perdarahan postpartum lebih besar.

\section{KESIMPULAN DAN SARAN}

\section{Kesimpulan}

Berdasarkan hasil penelitian yang telah peneliti lakukan dengan judul penelitian "Hubungan Usia Ibu Bersalin, Paritas dan Berat Bayi Lahir dengan Kejadian Partus Tak Maju di RSUD Ade. M. Djoen Sintang tahun 2020", maka hasil penelitian ini dapat disimpulkan:

a. Diketahui sebagian kecil ibu bersalin dengan usia berisiko ( $<20$ tahun dan $>35$ tahun) sebanyak 95 orang $(27,5 \%)$ dan sebagian besar ibu bersalin usia tidak berisiko (20-35 tahun) sebanyak 251 orang $(72,5 \%)$.

b. Diketahui sebagian kecil ibu bersalin dengan paritas 1 atau $>3$ sebanyak 102 orang $(29,5 \%)$ dan sebagian besar ibu bersalin dengan paritas 2-3 sebanyak 244 orang $(70,5 \%)$.

c. Diketahui sebagian kecil ibu bersalin dengan berat bayi lahir berisiko ( $\geq 4000$ gram) sebanyak 80 orang $(23,1 \%)$ dan sebagian besar ibu bersalin dengan berat bayi lahir tidak berisiko ( $\leq 4000$ gram) sebanyak 266 orang $(76,9 \%)$.

d. Diketahui sangat sedikit ibu bersalin dengan kejadian partus tak maju sebanyak 62 orang $(17,9 \%)$ dan hampir seluruh ibu bersalin dengan bukan partus tak maju sebanyak 284 orang $(82,1 \%)$. 
e. Diketahui nilai $\mathrm{p}$ value $=0,008$ ( $\mathrm{p}$.value $\leq \alpha=0,05$ ), dengan nilai $\mathrm{OR}=2,250$ yang artinya usia ibu bersalin yang berisiko yaitu $<20$ tahun dan $>35$ tahun mempunyai resiko terjadinya partus tak maju 2,250 kali lebih besar dari usia ibu bersalin yang tidak berisiko.

f. Diketahui nilai $\mathrm{p}$ value $=0,026$ ( $\mathrm{p}$.value $<\alpha=0,05$ ), maka Ho ditolak dan Ha diterima yang artinya ada hubungan antara paritas dengan kejadian partus tak maju. Nilai OR = 1,977 yang artinya paritas dengan jumlah persalinan 1 atau $>3$ mempunyai resiko terjadinya partus tak maju 1,977 kali lebih besar dari paritas degan jumlah persalinan 2-3 kali.

g. Diketahui nilai $p$ value $=0,040$ ( $p$.value $<\alpha=0,05$ ), maka Ho ditolak dan Ha diterima yang artinya ada hubungan antara berat bayi lahir dengan kejadian partus tak maju. Nilai OR = 1,953 yang artinya berat bayi lahir yang beresiko >4000 gram mempunyai resiko terjadinya partus tak maju 1,953 kali lebih besar dari berat bayi lahir yang tidak berisiko.

\section{Saran}

Berdasarkan hasil penelitian ini dapat disarankan untuk meningkatkan inovasi pelayanan dalam menangani kegawatdaruratan partus tak maju salah satunya melalui langkah penapisan sejak awal dengan pemeriksaan kehamilan pada ibu hamil sehingga faktor penyebab kasus partus tak maju seperti faktor usia ibu hamil yang beresiko tinggi, paritas dengan jumlah lebih dari 3 atau keadaan berat bayi lahir dapat di cegah sejak dini agar kejadian partus tak maju dapat dicegah sejak awal.

\section{DAFTAR PUSTAKA}

Data Rekam Medis. (2020). RSUD Ade Muhammad Djoen Sintang.

Fatoni, A.A. (2011). Hubungan Usia Ibu, Paritas dan Berat Lahir terhadap Persalinan Macet di Rumah Sakit Adji Darmo Lebak. http://repository.uinjkt.ac.id/dspace/bitstream/123456789/25484/1/Agus\%20Anang\%20Fat oni\%20-\%20fkik\%20.pdf

Fithri, H. (2011). Hubungan Paritas Dengan Lama Persalinan Kala II di Puskesmas Tengalrejo Yogyakarta Tahun 2011. http://digilib.unisayogya.ac.id/3781/1/NASKAH_HERMIA\%20FITHRI\%20LAILATUL\% 20HIDAYATI.pdf

Gultom, L. (2014). Faktor Yang Berhubungan Dengan Kejadian Partus Lama pada Ibu Bersalin di RSU Haji Medan Tahun 2014. http://ojs.poltekkesmedan.ac.id/pannmed/article/download/199/168

Kebijakan Pembangunan Kesehatan dan 5 Isu Strategis dalam Rapat Kerja Kesehatan Daerah Provinsi Kalimantan Barat Tahun 2019. https://dinkes.kalbarprov.go.id/wpcontent/uploads/2019/03/KEBIJAKAN-PEMBANGUNAN-KESEHATAN-5-ISUSTRATEGIS.pdf

Kemenkes RI. (2014). Rakor Kemenkes RI. Jakarta : Dirjen BIAC GIZI KIA

Kementrian Kesehatan RI. (2015). Sensus Penduduk Kesehatan. Jakarta : Kementrian Kesehatan RI

Manuaba, IBG. (2010). Ilmu Kebidanan Penyakit Kandungan Dan KB. Jakarta: EGC

Notoatmodjo, S. (2010). Metodologi Penelitian Kesehatan. Cetakan Kelima. Jakarta: Rineka Cipta

Profil Kesehatan Provinsi Kalimantan Barat tahun 2018. https://www.kemkes.go.id/resources/download/profil/PROFIL_KES_PROVINSI_2018/20 _Kalbar_2018.pdf

Purwaningsih \& Fatmawati. (2010). Asuhan Keperawatan Maternitas. Yogyakarta: Nuha Medika 
Puspita, E. (2014). Asuhan Kebidanan pada Persalinan Cetakan I. Jakarta: Trans Info Medika Ruqaiyah. (2019). Faktor yang Berhubungan Terhadap Kejadian Partus Lama di Rumah Sakit $\begin{array}{llll}\text { AL Jala } & \text { Ammari } & \text { Makassar }\end{array}$ https://ojs.akbidpelamonia.ac.id/index.php/journal/article/view/135

SUPAS. (2015). https://sirusa.bps.go.id/sirusa/index.php/dasar/pdf?kd=2\&th=2015

Varney, H., \& Kribes, J. (2013). Buku Ajar Asuhan Kebidanan (1st and 2en ed). Jakarta: EGC World Health Organization. (2014). Maternal Mortality. https://www.who.int/mediacentre/news/releases/2014/maternal-mortality/en/

World Health Organization. (2019). Maternal Mortality. https://www.who.int/news-room/factsheets/detail/maternal-mortality 